\title{
Alternative methods in tracking sources of microbial contamination in waters
}

\author{
M Cimenti ${ }^{1}$, A Hubberstey ${ }^{2}$, JK Bewtra ${ }^{1}$ and N Biswas ${ }^{1 *}$ \\ ${ }^{1}$ Civil \& Environmental Engineering Department, University of Windsor, 401 Sunset Avenue, Ontario N9B 3P4, Canada \\ ${ }^{2}$ Biological Sciences Department, University of Windsor, Ontario, Canada
}

\begin{abstract}
A key factor in the management and remediation of impaired ground- and surface water is the ability to distinguish the sources of faecal contamination. Several approaches have been adopted as microbial source tracking methods (MST), which are generally classified as culturing, phenotypic, genetic, and chemical MST. None of the techniques used thus far can be considered a standard; important factors, such as the statistical correlation between the source and the faecal indicator and the understanding of the environmental fate of the faecal pollutants, still need attention.

The most promising MST methods available today are based on the genetic fingerprinting of faecal micro-organisms. However, research is very active also in the investigation of pharmaceuticals and personal care products discharged in the environment together with faecal waste.

An updated overview of MST methods to distinguish human from animal sources of faecal pollution is presented here, focusing particularly on the potentialities of new chemical tracers.
\end{abstract}

Keywords: faecal contamination, microbial source tracking methods, bacterial source tracking methods, pharmaceuticals and personal care products

\section{Introduction}

As a consequence of the serious health threats posed by waterborne pathogens, faecal contamination is one of the main quality factors in drinking water, in aquaculture and in recreational water. Traditionally, the evaluation of the health risk for waters contaminated by faeces is obtained through the quantification of certain indicators, and only rarely by the direct measurement of the real hazard, which is the actual concentration of the pathogens. The most commonly used faecal indicators are microorganisms that are always present in faeces, and are unable to reproduce outside the intestinal tract. In fact, enteric microorganisms and pathogens should disappear from the water body after a finite period from the contamination event. In order to obtain a reliable estimate of the health risks, faecal indicators must satisfy certain criteria defined by Gerba (Maier et al., 2000; Table 1). These organisms are not necessarily source-specific, they can be hosted indistinctively by humans, farm animals or wildlife. Consequently, the typical indicators (e.g. faecal coliforms, E. coli and enterococci) give a good estimate of the health risks only in the case of drinking water, for which there is zero tolerance to faecal contamination (James and Evison, 1979; Maier et al., 2000). On the other hand, the use of non-sourcespecific faecal indicators often results in a vague estimate of health risks in aquaculture and recreational waters, where the presence of these contaminants is tolerated within specific limits. In these circumstances, the detection of faecal contaminants should be obtained simultaneously to the identification of the sources of pollution.

\footnotetext{
* To whom all correspondence should be addressed.

正 (403) 210 9589; fax: (519) 971-3686;

e-mail: biswas@uwindsor.ca

Received 30 August 2005; accepted in revised form 1 February 2007.
}

\begin{tabular}{|c|c|}
\hline \multicolumn{2}{|c|}{\begin{tabular}{|c|} 
TABLE 1 \\
$\begin{array}{c}\text { Characteristics of the ideal faecal indicator, adapted } \\
\text { from Maier et al. (2000) }\end{array}$
\end{tabular}} \\
\hline 1 & $\begin{array}{l}\text { The indicator must be present whenever faecal con- } \\
\text { tamination is present. In case of a micro-organism, it } \\
\text { should be a member of the microflora of warm-blooded } \\
\text { animals; in case of chemical substance it should be } \\
\text { associated solely to faecal discharges. }\end{array}$ \\
\hline 2 & $\begin{array}{l}\text { The indicator should not be present in the environment } \\
\text { other than when there is faecal contamination. In the } \\
\text { case of a micro-organism, it should not grow in the } \\
\text { environment. }\end{array}$ \\
\hline 3 & of environ- \\
\hline 4 & $\begin{array}{l}\text { The concentration of indicator should be greater or at } \\
\text { least equal to that of the pathogen. }\end{array}$ \\
\hline 5 & $\begin{array}{l}\text { The indicator must have a reasonably longer 'survival } \\
\text { time' (persistence) if compared to the most resilient } \\
\text { pathogen. }\end{array}$ \\
\hline 6 & $\begin{array}{l}\text { The quantification of the indicator (including sampling } \\
\text { and measurement) should be faster, easier to perform } \\
\text { and more sensitive than that of the pathogen. }\end{array}$ \\
\hline 7 & $\begin{array}{l}\text { The quantification of the indicator (including sampling } \\
\text { and measurement) should be less expensive than that } \\
\text { of the pathogen. }\end{array}$ \\
\hline
\end{tabular}

The techniques to identify the sources of faecal contamination in water have been defined as microbial source tracking (MST) methods, or bacterial source tracking methods. MST methods are based on the detection of a 'tracer' that can be used as a fingerprint to obtain a complete characterisation of the contamination (i.e. type of pollution, source, timing, severity, etc.). The tracer can be either a faecal micro-organism or a chemical 


\begin{tabular}{|l|l|}
\hline \multicolumn{2}{|c|}{ TABLE 2 } \\
Classification of MST methods \\
\hline pathogens monitoring of & $\begin{array}{l}\text { Human enteric viruses (Enterovirus, Adenovirus, } \\
\text { Norwalk virus) } \\
\text { Eggs of helminths (intestinal worms) }\end{array}$ \\
\hline Culturing methods & $\begin{array}{l}\text { Faecal coliforms/faecal streptococci (FC-FS ratio) } \\
\text { Faecal streptococci species identification } \\
\text { FC-FS ratio shift } \\
\text { Bifidobacteria spp. (sorbitol-fermenting Bifidobacteria) } \\
\text { Rhodococcus coprophilus } \\
\text { Bacteroides spp. } \\
\text { Pseudomonas aeruginosa } \\
\text { Phages of Bacteroides fragilis } \\
\text { F-RNA phage subgroup } \\
\text { Streptococcus bovis }\end{array}$ \\
\hline Phenotypic methods & $\begin{array}{l}\text { Antibiotic resistance analysis (ARA) } \\
\text { or multiple antibiotics resistance analysis (MAR) } \\
\text { Serogrouping } \\
\text { Carbon utilisation profile }\end{array}$ \\
\hline Genetic methods & $\begin{array}{l}\text { Ribotyping } \\
\text { Amplified fragment length polymorphism (AFLP) } \\
\text { Pulse-field gel electrophoresis (PFGE) } \\
\text { Repetitive PCR (rep-PCR) } \\
\text { Denaturating gradient gel electrophoresis (DGGE) } \\
\text { Host-specific molecular markers (LH-PCR; T-RFLP) }\end{array}$ \\
\hline Chemical methods & $\begin{array}{l}\text { Faecal stanols } \\
\text { Fluorescent whitening agents } \\
\text { Sodium tripolyphosphate } \\
\text { Long-chain alkylbenzenes } \\
\text { Caffeine } \\
\text { Musk fragrances } \\
\text { Estrogens } \\
\text { Human pharmaceuticals } \\
\text { Animal growth promoters }\end{array}$ \\
\hline
\end{tabular}

on the list of major water pollutants (e.g. Giardia lamblia; Cryptosporidium parvum), and there is increasing concern for other zoonotic waterborne pathogens (Slifko et al., 2000), particularly in relation to the intensive farming operations, commonly defined as concentrated animal feedlot operations (CAFOs). As a matter of fact, CAFOs constitute a significant environmental stressor because of the very high load of faecal waste produced, and simultaneously because they are an ideal incubator for the development of antibioticresistant organisms, due to the intensive use of drugs as therapeutics or growth promoters.

Accordingly, CAFOs are the ideal environment for the selection of new viruses, which are only rarely infective for humans, but could be spread through groundwater. MST methods play a key role also in epidemiological studies for the identification of the limits of tolerance to faecal contaminants with the various final uses of water. In surface waters the quality targets are related to uses such as drinking, fish-farming and recreational waters. The typical stressors for surface water are industrial and residential sewer systems, septic tanks, urban wastewater treatment plants, animal farms, CAFOs, urban waste dumps, and wild animals. The choice of the appropriate MST method should be finalised to distinguish among these sources.

Coastal or estuarine waters also present a diversified set of faecal sources. It is commonly believed that marine water is an

substance discharged with the faecal waste. In the first case, the microbe should reproduce only in the intestinal tract of a specific host (the source) in addition to satisfying the same basic criteria mentioned above for a generic faecal indicator organism (Table 1). In the latter case, the chemical should be found only in the diet of a specific host or should be discharged only with faecal waste from a specific source. Another fundamental requisite is the environmental fate of the tracer, which should be similar to that of the water-borne pathogens. Nevertheless, it can be convenient to use an indicator with a longer lifespan, particularly when it is required to define the vulnerability to faecal pollution of an aquifer.

MST methods are a fundamental tool in water management. For instance, the effective remediation of impaired waters requires the quantification of the contaminant loads (and accordingly of the contamination source) that the water body can bear without negative effects on quality. Once these loads, also called total maximum daily load (TMDL), have been obtained for each stressor, the administrator of the water body can decide which action should be taken in order to effectively reduce the impact. Environmental agencies are showing increasing interest in implementing protocols for monitoring water quality, including MST, to define the TMDL (US-EPA, 2001; Bernstein, 2002; USGS, 2004).

MST methods play an important role also in relation to the emerging problem of zoonoses. In fact, although the attention of health organisations is presently focused on food-borne zoonoses, a number of pathogens transmitted by animals is already unsuitable environment for endogen microbes, since the survival of pathogens and other intestinal micro-organisms is highly reduced. Nevertheless, it has been observed that the persistence of enteric bacteria can be significantly increased by other environmental factors such as turbidity, concentration of suspended solid, turbulence, etc. (Alkan et al., 1995; Yang et al., 2000). Therefore, the choice of MST methods needs specific attention in the marine environment. It is worth noting that in aquaculture other important factors such as toxins produced by algae (e.g. Dinophysis spp.; Cyanobacteria (Haider et al., 2003)) can also represent a serious health risk.

Groundwater is considered relatively less vulnerable to faecal pollution as a consequence of the filtrating effects of soil layers (Bitton and Gerba, 1984). The most common sources of faecal pollution are septic systems, sewers, cesspits from CAFOs, and wildlife droppings. Several studies have been published on the fate of micro-organisms in groundwater in relation to the hydrogeological and geological characteristics of the aquifers (Matthess and Pekdeger, 1981; Conboy et al., 2000; Gordon et al., 2003). The identification of faecal pollution sources in groundwater is often very difficult, although geographic and hydro-geological information on the surrounding area can provide valuable clues.

The first extensive review on MST methods was published by Sinton (1998). Other studies published recently by Scott et al. (2002), Simpson et al. (2002) and Meays et al. (2004) focus mainly on genetic and phenotypic methods. In this paper, an updated overview of MST methods is given, focusing particu- 
larly on the potentialities of new chemical methods, such as the detection of drugs and personal care products to distinguish human from CAFO sources of faecal pollution.

\section{Classification of microbial source tracking methods}

Various approaches can be applied to distinguish sources of faecal contamination. The classification of MST is usually made according to the distinctive characteristic of the pollutant used as a marker. Four main groups are identified, namely culturing, phenotypic, genetic and chemical MST methods. Indeed, the direct detection of human or animal specific pathogens, such as enteric viruses and intestinal worms, should also be included. This approach, which avoids the use of indicators, is the most effective way of determining the health risks associated with a target waterborne pathogen. However, it is possible that a body of water polluted by faecal waste contains other pathogens. Furthermore, the detection is complex, time-consuming and expensive.

In the culturing methods a microbial species hosted uniquely by one of the stressor sources (humans, or farming animals, or wildlife) is detected by the use of a selective recovery medium. Alternatively, concentration ratios characteristic of a faecal source are obtained by the enumeration of non-specific indicators.

In the phenotypic methods a typical trait of the faecal indicator is used as distinctive characteristic. Several phenotypic characters can be used, but the method that seems more effective is the analysis of antibiotic resistance profile (ARA).

The group of genetic methods involves the use of DNA fingerprinting to identify a source-specific indicator or also to identify a non-specific faecal micro-organism that has developed peculiar genetic traits after adaptation to the intestinal conditions of a specific faecal source.

In chemical methods the tracer is a molecule that can be associated uniquely to one type of faecal pollution. Here the development of powerful analytical techniques plays a key role. The difficulty to correlate the environmental fate of the tracer to that of the pathogens is one of the limitations of these methods.

\section{Direct detection}

Because enteroviruses possess a high degree of host-specificity, their detection in water is a clear indication of human faecal contamination and gives the most direct assessment of the health risks. Nonetheless, water polluted by human faeces does not necessarily contain enteroviruses, and therefore this method is not always reliable to identify faecal sources. Jagals et al. (1995) investigated cytopathogenic viruses in a river exposed to faecal pollution produced by domestic animals and by humans. Other enteroviruses (echovirus, coxsackievirus B, coxsackievirus A, poliovirus, hepatitis A virus, Norwalk virus, reoviruses, and rotaviruses) have been used to monitor wastewater treatment plants and groundwater (Sedmak et al., 2003; Fout et al., 2003). Molecular techniques for the detection of enteric pathogens were reviewed by Toze (1999). As stated previously, the main disadvantage of this alternative is that the absence of enteroviruses in a water sample does not exclude faecal pollution.

Also helminth eggs (of host-specific intestinal worms) were considered as a faecal source indicator by Gaspard et al. (1995) and Malicki et al. (2001), but there is still not enough evidence to evaluate how effective this approach is.

\section{Culturing methods}

The culturing methods are based on the isolation of a microorganism species (or of a group of species) from all the microbes polluting a body of water. This micro-organism should be exclusively a member of the microflora of one of the suspected sources. In the case of bacteria, the isolation is usually obtained by culturing a dilution of the water sample in a selective medium, or more often by membrane filtration technique. Sometimes the procedure comprises other steps to confirm the identity of the presumptive isolate. Total and faecal coliforms are the most commonly used indicators of faecal pollution in water but are not source-specific. When the indicator is a protozoan or virus, specific isolation techniques are used. The drawback of the culturing methods is that only few organisms are host specific and satisfy simultaneously the criteria for the faecal indicator (Maier et al., 2000); moreover, the culturing media are only rarely completely selective.

\section{Faecal streptococci}

The group of faecal streptococci comprises the enterococci species (Enterococcus faecium, E. faecalis, E. durans, E. avium, E. gallinarum) together with two non-enterococci (Streptococcus equinus, $S$. bovis). The concentration is obtained by membrane filtration, using m-Enterococcus or KF agar as a growth medium. Faecal streptococci have been studied extensively in the past, and most studies have revealed that they are more persistent than faecal coliforms (FC) in groundwater (Geldreich, 1976).

Three different methods have been proposed for faecal streptococci as indicators of faecal contamination sources:

- Faecal coliforms vs. faecal streptococci ratio (FC/FS): According to Geldreich et al. (1969), a ratio of greater than 4 indicates human faeces $(\mathrm{FC} / \mathrm{FS}>4)$, while less than 0.7 indicates animal faeces (FC/FS $<0.7$ ).

- Species identification: This method is based on the different ratio of enterococci and streptococci species in faeces determined statistically for different warm-blooded animals; according the statistical studies human faeces contain predominantly enterococci species, while animal faeces have a significant number of non-enterococci (Geldreich et al., 1969; Geldreich, 1976; Wheeler et al., 2003). In this case, the use of a specific growth medium for non-enterococci is required.

- FC/FS ratio shift: This approach is based on the different die-off coefficients for faecal coliforms and faecal streptococci in stored samples. Human sources, dominated by enterococci that are typically more persistent, should initially exhibit a high $\mathrm{FC}$ to $\mathrm{FS}$ ratio $(>4)$, which then decreases with time. Non-human sources, dominated by $S$. bovis and $S$. equinus, which are less persistent than faecal coliforms, should initially have a low FC to FS ratio $(<0.7)$ that increases with time (Geldreich et al., 1969; Geldreich, 1976).

These methods, although rapid, requiring minimal expertise and sometimes with satisfactory outcomes (Jagals et al., 1995; Jagals et al., 1996; Wheller et al., 2003), have proven unreliable in recent studies and they are now being opposed (Scott et al., 2002; Simpson et al., 2002). 


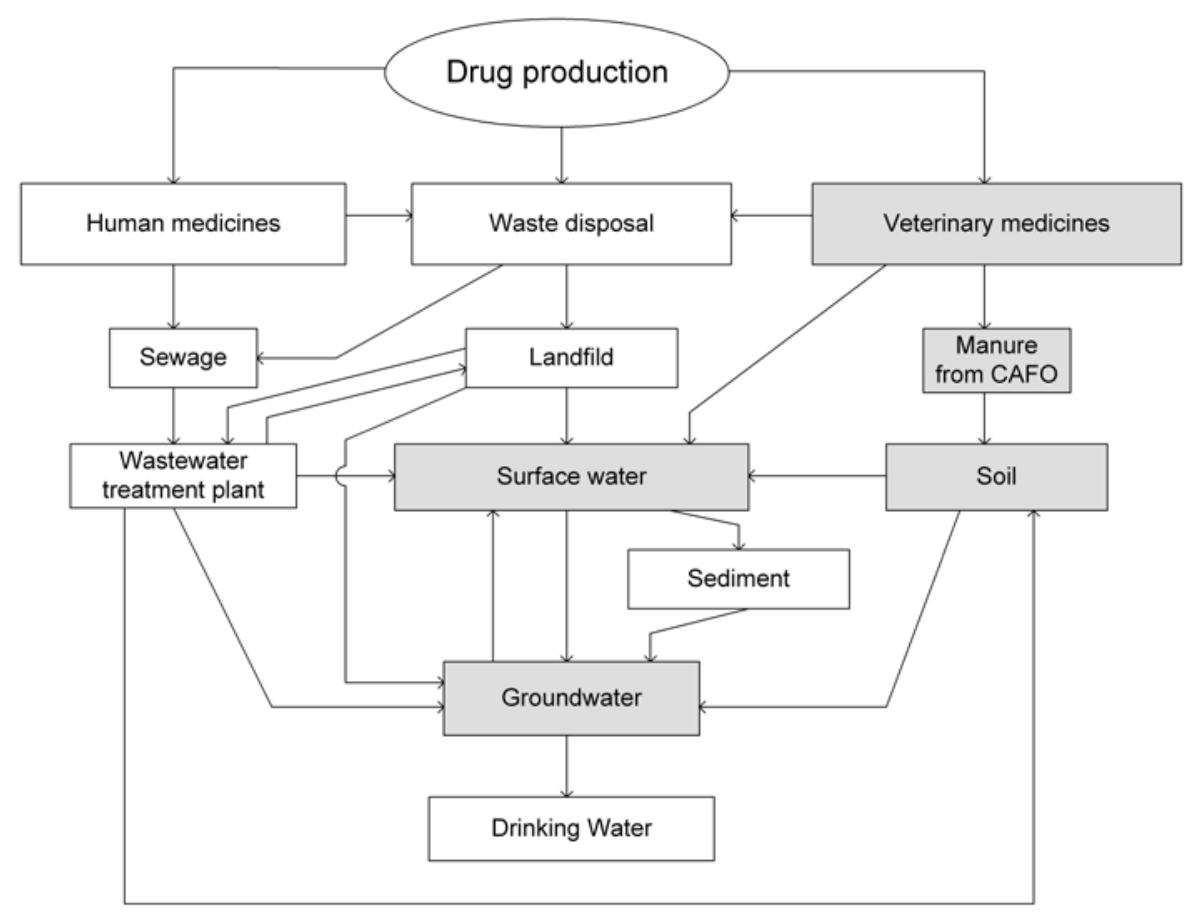

Figure 1

Pathways of human and veterinary drugs in the environment (adapted from Kümmerer, 2001)

\section{Bifidobacteria species}

Bifidobacteria (a genus in the family Actinomycetaceae) is a group of micro-organisms that are present in very high concentrations in human faeces, in particular B. adolescentis and $B$. longum. Certain species have been found also in animals but never in unpolluted environments. The Bifidobacteria hosted exclusively by humans have the ability to ferment sorbitol; this subgroup, called sorbitol-fermenting Bifidobacteria (SFB), is composed of B. adolescentis and B. breve, and can be used as an indicator of human source of faecal pollution.

Presently, only one growth medium has been formulated for the isolation of SFB: the human Bifidobacteria sorbitol-fermenting agar (HBSA), used after membrane filtration as described by Mara et al. (1983). This method proved to be reliable (Jagals et al., 1995; Jagals et al., 1996; Long et al., 2003) but there is still the need to improve selectivity and sensitivity of the growth medium.

Other Bifidobacteria species have been recently used as source-specific indicators: Lynch et al. (2003) used the Bifidobacterium medium (BFM), developed by Nebra et al. (1999), combined with colony hybridisation (digoxigenin (DIG-)labelled oligonucleotide probe) to identify $B$. adolescentis. On the other hand, Nerba et al. (2003) proposed the use of B. dentium (human specific) as indicator organism. The distribution of Bifidobacteria in different environments has been described by Ventura et al. (2001) and by Gavini (2003).

\section{Rhodococcus coprophilus}

$R$. coprophilus is an actinomycete that can be found in herbivore dung and pasture runoff, but it is absent in human faeces. For this reason it can be used as a specific indicator of faecal contamination from grazing animals. Its persistence in waters and sediments is considerably longer than that of faecal streptococci and other commonly used faecal indicators. The method for the recovery and enumeration of this species is described by Oragui et al. (1983), and recently, molecular techniques have been applied to detect this species (Savill et al., 2001). R. coprophilus can be a very reliable indicator, as demonstrated in recent studies (Jagals et al., 1995; Long et al., 2003; Gilpin et al., 2002; Gilpin et al., 2003).

\section{Bacteroides species}

The Bacteroides genus is among the most abundant bacteria found in human faeces, 100 times greater in number than E. coli. Since they are almost absent in animal faeces, these species have a potential role as indicator of anthropogenic sources. In particular, $B$. fragilis has been found only in human faeces at very high concentrations. Only few methods for recovery and enumeration of Bacteroides species are available. The most common way to isolate $B$. fragilis is by use of Bacteroides bile esculin agar (BBE) as described by Livingston et al. (1978); another method involves the use of WCPG medium, after membrane filtration (Tartera et al., 1987). Despite their high potential as source-specific indicators, Bacteroides species have not attracted much attention recently because of their short persistence in the waters.

\section{Phages of Bacteroides fragilis}

As previously mentioned, some Bacteroides species are hostspecific, in particular $B$. fragilis, but have only a short lifespan in the environment.

Tartera et al. (1987) used a bacteriophage of B. fragilis, a virus infecting this bacterial species, as a human specific faecal indicator. This bacteriophage is specific and significantly more persistent in the water environment than $B$. fragilis (the viral target). The method of enumerating $B$. fragilis bacteriophages is the double-layer agar technique (with plaque detection), using Bacteroides phage recovery medium (BPRM) (Pepper et al., 1995). Although this technique is not very complex, and B. fragilis bacteriophages are highly specific, there are still uncertainties about the reliability of this MST method (Maier et al., 2000; Sinton et al., 1998). 


\section{F-RNA phage subgroup}

F-RNA phages are a group of icosahedral phages that attach specifically to the F-pili of bacteria (filamentous structures on the cell walls of ' $m$ ' bacterial strains). F-RNA coliphages infect coliform bacteria, and have been classified in three subgroups; Subgroups II and III have been isolated only in human faeces, while Subgroup I was found only in non-human mammals. There are several methods of detecting coliphages, and, once detected, the subgroups can be identified using immunological or genetic tests (Calci et al., 1998; Cole et al., 2003). What limits the use of this method is the complexity of detection.

\section{Phenotypic methods}

This set of MST methods is based on the detection of phenotypic characteristics developed by different lineages of the same bacterial species hosted in animals or humans. These phenotypic differences are caused by the different conditions to which the microbes are exposed in the intestinal tract of the hosting species. The drawback of phenotypic methods is that different species of enteric micro-organisms can show very similar biochemical responses, potentially causing a nonunique phenotypic fingerprint. However, the detection of multiple phenotypic characteristics increases the accuracy of the method.

\section{Antibiotic resistance analysis}

Antibiotic resistance analysis (ARA) is used to differentiate bacteria of the same species by their varying response to antibiotic treatment. In fact, the bacterial flora present in the human intestine is exposed to conditions different from that typical of domestic animals, because of the difference in the dietary uptake of antibiotics and other pharmaceuticals. This situation generates bacterial strains that respond differently to antibiotic treatment, giving a characteristic profile that can be used as a fingerprint to identify faecal sources.

The procedure, simple but time-consuming, involves the isolation and culturing of the target organism, followed by replica-plating of the isolates on media with increasing antibiotic concentrations. Typically, several antibiotics are considered singularly or in mixtures. After incubation, the plated colonies are observed and the susceptibilities are recorded for each antibiotic to generate an 'antibiotic resistance profile', which is compared to known profiles typical of the strain of the bacteria (Whitlock et al., 2002; Wiggins et al., 2003).

ARA has been successfully used for different indicator organisms: sulphate-reducing Clostridia as indicators of the practice of disposing pig manure to land (Huysman et al., 1993), faecal streptococci (Wiggins, 1996), enterococci (Booth et al., 2003; Graves et al., 2002). The main limitation of ARA is that an adequate database of profiles is needed.

\section{Serogrouping}

This method is based on the presence of different somatic (O) antigenic determinants in bacterial strains of the same species. Sero-grouping has been successfully used in a set of samples coming from different faecal sources, a good percentage of which has been successfully typed with an insignificant overlapping between the predominant serotypes (Praveen et al., 2001). Also this method necessitates an adequate databank of anti-sera profiles.

\section{Other phenotypic methods}

The use of the carbon utilisation profile to distinguish faecal sources was reported by Hagedorn et al. (2003). This technique is based on the utilisation of the BIOLOG system to determine the profile. The system can identify over 2000 species of microorganisms and it was used to differentiate among several Enterococcus species with good results. Because this method has been used only in one case, further study is needed to evaluate its effectiveness as an MST method.

\section{Genetic methods}

Genetic methods use the genotypic profile of intestinal bacteria to discriminate sources of faecal pollution. The indicator organisms for which the DNA is analysed can be host-specific - e.g. Bifidobacterium dentium, see Nebra et al. (2003) - or non-specific (e.g. Escherichia coli); in the latter case the adaptation to a host must result in a characteristic genetic profile. Several genetic techniques have been applied as MST methods, and because of their precise nature, they are currently preferred among all the other MST alternatives. However, genetic MST methods necessitate an adequate database of profiles, which can change with the geographic location and can also vary in time.

Since this paper is intended as a general overview of all the possible MST methods, only the main techniques are reviewed. For a more detailed description of the genetic method applied as MST the reader is referred to the works published by Simpson et al. (2002) and Meays et al. (2004).

\section{Ribotyping}

Ribotyping is a method of DNA fingerprinting that examines the rRNA genetic material in each bacterial isolate and produces a banding pattern image using oligonucleotide probes after treatment of genomic DNA with restriction endonucleases. This image is used to classify the indicator organism by strains, and is the basis for comparison of unknown to known sources. The procedure implies the DNA extraction and purification, followed by its digestion with restriction enzymes; then the DNA is separated via gel electrophoresis, denatured and blotted onto a membrane; it follows the hybridisation with specific-rRNA DNA probes and finally the membrane is exposed to a chemiluminescent substrate and digitally imaged (Scott et al., 2002).

The ribotyping technique was used in several studies. Parveen et al. (1999) were the first to successfully apply this method to discriminate human from animal species of E. coli; similar results were also obtained by Carson et al. (2001). Hartel et al. (2003) pointed out variations of genetic profiles in wild life, while Scott analysed the variations of genetic profiles with geographic location (Scott et al., 2003). The necessity of different databases for each geographic region can represent a limitation for this and all other methods based on the genetic profiles of non-specific bacteria.

\section{Repetitive PCR DNA fingerprinting}

This method uses interspersed repetitive DNA sequences located in different parts of the target indicator genome to generate specific fingerprints. The two alternative techniques that proved to be suitable as MST are the repetitive extragenic palindrome sequence PCR (rep-PCR) and the extragenic repeating elements PCR (Box-PCR) (Dombek et al., 2000; Baldy-Chdzik 
et al., 2003; Borges et al., 2003; Albert et al., 2003; McLellan et al., 2003; Carson et al., 2003).

\section{Genetic markers}

These methods can distinguish the origin of faecal pollution through the identification of a labelled target gene sequence from the DNA of the indicator bacteria. The considerable advantage of using genetic markers is that culturing is not required. Bernhard et al. (2000a; 2000b) were the first to use this technique as MST method; in particular they used human and animal specific genetic markers by amplifying $16 \mathrm{~S}$ ribosomal DNA fragments from Bifidobacteria species and from members of the Bacteroides-Prevotella group, on which they performed length heterogeneity PCR (LH-PCR) and terminal restriction fragment length polymorphism analyses (T-RFLP) (Field et al., 2003; Berhard et al., 2003). The same researchers recently applied these techniques on the genome of Bacteroides genus. Khatib et al. (2003) selected STII toxin gene from E. coli as the target sequence to identify pig faecal pollution. Recently, Simpson et al. (2004) used universal eubacterial primers and BacteroidesPrevotella group-specific primers to identify equine sources.

\section{Other fingerprinting methods}

Other DNA fingerprinting techniques were tested as MST methods: Dicuonzo et al. (2001) used pulse-field gel electrophoresis (PFGE); Farnleiner and co-workers (2000) adopted the denaturating gradient gel electrophoresis (DGGE) technique; Gaun et al. (2002) and Leung et al. (2004) applied amplified fragment length polymorphism (AFLP) analysis; Seurinck et al. (2003) assessed 16S-23S rRNA intergenic spacer region (ISR)-PCR; Tsai et al. (2003) used magnetic capture hybridisation - polymerase chain reaction (MCH-PCR); El Fantroussi et al. (2003) selected oligonucleotide micro-arrays to characterise rRNA extracted from microbial populations without PCR amplification.

Most of these techniques were applied in single studies; therefore, more research is needed to access their potentialities as MST methods.

\section{Chemical methods}

Chemical methods are based on the detection of a substance (chemical tracer) that is related to a specific faecal source but is not found in unpolluted waters. In some cases the tracer is directly associated with faeces (it is released from the host's intestine), while in others it is simply discharged together with faeces in wastewaters.

These methods can only give limited information on the health risks because they are not easily correlated to the presence of waterborne pathogens. Nevertheless, their detection can give a certain indication of the origin of pollution and of the vulnerability of the body of water.

\section{Digestion metabolites}

Many substances produced in the digestive system of warmblooded animals can be detected in faecal wastewaters. Ammonia (often measured in water samples as $\mathrm{NH}_{3}-\mathrm{N}$ ) is one of the main metabolites, but it cannot be considered a good index of faecal contamination because it is produced also by rotting vegetation, and it has been found also in unpolluted waters. Other human metabolites, like uric acid and urobilin, have been considered as MST but they do not seem specific enough (Sinton et al., 1998).
Only faecal sterols have been successfully used as sourcespecific faecal indicators. Faecal sterols are a group of cholestane-based sterols found in faeces. They are comprised of coprostanol, sitosterol,campestanol and 5-beta-stanol. Coprostanol is the principal human faecal sterol and can be used as a reliable tracer of faecal pollution (Sinton et al., 1998; Leeming et al., 1996a; Atherholt et al., 2003). The analysis of faecal sterols is based on high-resolution gas chromatography and mass spectrometry (Jayasinghe et al., 1998; Borjesson et al., 1999; Truong et al., 2003) and has been used effectively in studies by Leeming et al. (1996b), Maldonado et al. (1998), Leeming et al. (1998), Schonning et al. (2002), Suprihatin et al. (2003), and Isobe et al. (2004).

Sinton et al. (1998) proposed the direct detection of human or animal DNA sloughed off the intestinal tract as a chemical MST method, but no study of this kind has been done. Another approach that can give interesting results, but has not been tested yet, is the use of the isotopic partitioning ratios for elements in the major compound found in human or animal metabolites in analogy to studies done in forest ecosystems (Garten, 2006).

\section{Detergents and brighteners}

Chemicals contained in liquid and powder detergents are usually associated with discharges containing faecal material. Three main groups of substances have been investigated as faecal indicators: fluorescent whitening agents (FWAs), sodium tripolyphoshate (STPs) and long-chain alkylbenzenes (LBAs) (Sinton et al., 1998). FWAs are incorporated in powder detergents and can be easily detected using fluorometric measurements or thin layer chromatography (Gilpin et al., 2002; Close et al., 1989; Hayashi et al., 2002; Poiger et al., 1999). STPs are a major component of washing powders and can be measured by ion-exchange combined with colorimetric techniques. LBAs are a group of synthetic hydrocarbons intensively used as anionic surfactants in detergents, and their determination can be done using organic solvent extraction followed by gas chromatography (Holts et al., 1992; Martins et al., 2002). LBAs have also been investigated in relation to soil pollution (Jensen, 1999; Binetti et al., 2000; Carlsen et al., 2002).

Because detergents and brighteners can also be released with industrial wastewaters, their application as MST methods should be carefully considered in relation to the characteristics of the body of water.

\section{Caffeine and fragrances}

Caffeine was detected for the first time in wastewaters by Sievers and co-workers three decades ago (Sievers et al., 1977). Seiler et al. (1999) attempted for the first time to use caffeine as a faecal indicator in groundwater. In their study they were able to detect and quantify this substance in several samples using HPLC without the need of pretreatment extraction; however, they concluded that caffeine is not a good faecal indicator (and neither a good MST) because it was not detected in several samples of polluted water. New techniques have been proposed to improve the analytical resolution for trace contaminants (Burkhardt et al., 1999; Piocos et al., 2000), and recently caffeine has been reused as a tracer of human faecal sources by Standley et al. (2000), Weigel et al. (2002), and recently by Buerge et al. (2003a).

Synthetic musk fragrances, including polycyclic musks (Galaxolide - HHCB; Tonalide - AHTN; Traseolide - ATTI; Phantolide - AHMI; Celestolide - ADBI; and Cashmeran - DPMI) 
TABLE 3

List of the target emerging contaminants in waters, adapted from USGS (2003)

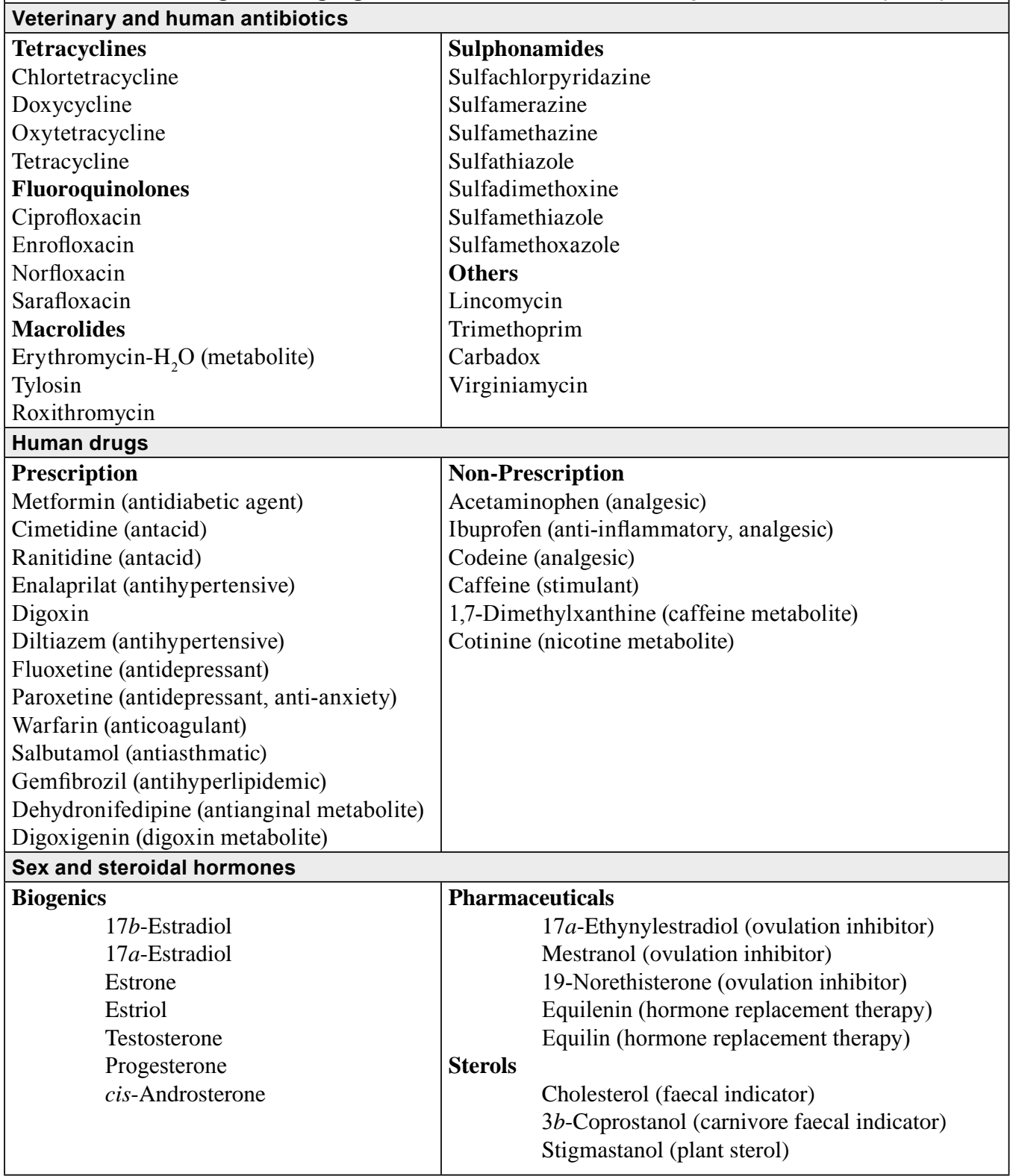

and nitro musks (musk xylene-MX; and musk ketone-MK), are chemicals widely used in cosmetics and in personal and household care products. Musk fragrances were studied for the first time as tracers of human faecal contamination by Standley et al. (2000), and are currently attracting the attention of the scientific community (Fromme et al., 2000; Buerge et al., 2003b; Ricking et al., 2003; Lee HB et al., 2003; Peck et al., 2004); their environmental fate is also the object of study (Heberer, 2003). Musk fragrances are detected by solid or supercritical-fluid extraction followed by gas chromatography/mass spectrometry.

Although the presence of caffeine and musk fragrances is an indication of human sources, it is not yet clear whether they can be suitable indicators of faecal pollution.

\section{Pharmaceuticals and other drugs}

The awareness of the potential risks brought about by pharma- ceuticals in the environment started growing in the mid 1990s, when scientists observed deleterious effects on fish and other freshwater fauna as a consequence of the presence of endocrine disrupting agents at trace levels in aquatic ecosystems (Halling-Sorensen et al., 1998; Daughton et al., 1999; Jorgensen et al., 2000; Sumpter, 2003; Petrovic et al., 2004). During the same period, a number of popular drugs were detected at concentrations ranging from nanograms to micrograms per litre in groundwater (Eckel et al., 1993; Holm et al., 1995), surface water, and in particular outlet streams from sewage treatment plants (Ternes, 1998).

Nowadays, the study of pharmaceuticals and personal care products (PPCPs) in the environment is an important topic in environmental studies, and research in this field is growing exponentially. A comprehensive review of the studies on PPCPs in the environment is given by Kümmerer (2001) and Daughton et al. (2001). The high level of attention given by environmental 


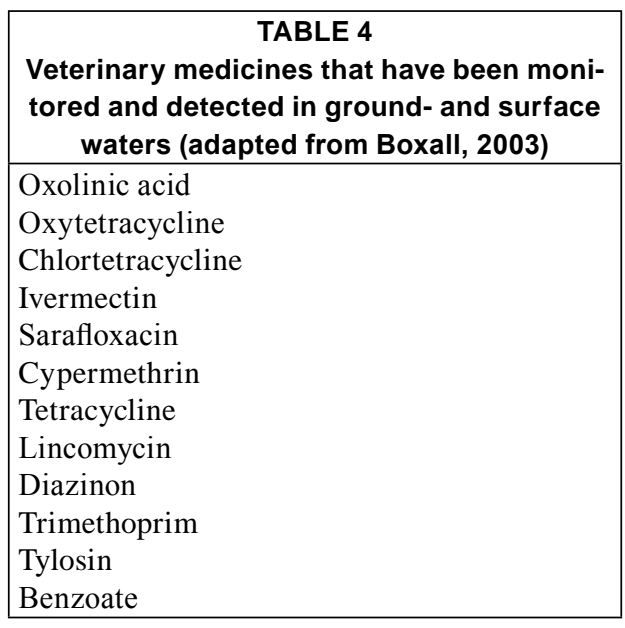

agencies to PPCPs gives evidence of the importance of these pollutants (Barnes et al., 2002; Kolpin et al., 2002; US-EPA, 2004), and a list of the 'emerging contaminants' has been prepared by USGS (2001).

The unfolding of this new dimension in environmental science is favoured mainly by the progress in the instrumental analysis of trace contaminants. Liquid and gas chromatography coupled with tandem-mass spectrometry (Marchese et al., 2003; Hilton et al., 2003; Loffler et al., 2003; Ferrer et al., 2003) are the prominent techniques among those developed in this field (Petrovic et al., 2003).

The drugs found most frequently in surface and wastewaters in North America are clofibric acid (cholesterol control drug), carbamazepine (antiepileptic drug) and salicylic acid (Weigel et al., 2002; Ternes, 1998, Lee et al., 2003b, Metcalfe et al., 2003, Boyd et al., 2003; Sacher et al., 2003; Bila et al., 2003). Clofibric acid has also recently been proposed as a marker for anthropogenic contamination (Clara et al., 2004). In order to evaluate the potentialities of these drugs to distinguish faecal sources it is necessary to understand their environmental fate better.

Antibiotics and other drugs used as growth promoters in CAFO are also capturing the attention of environmental scientists in Europe and North America (USGS, 2003; Boxall et al., 2003; Scribner et al., 2003; Boxall et al., 2004). As previously mentioned, the main concern in relation to these drugs is their environmental fate, and in particular the risk of favouring the development of antibiotic-resistant micro-organism (i.e. super-bugs). There is still uncertainty about the quantities of growth promoters currently used in CAFO (Blackwell, 2003), but some of the most persistent drugs have already been found in watersheds (Boxall et al., 2003) (Table 3) and for this reason they could be used as tracers of CAFO faecal pollution. There is no published study on the use of growth promoters as MST, but once again the feasibility of this approach is contingent on by the understanding of the environmental fate of these drugs.

\section{Summary and concluding remarks}

Microbial source tracking (MST) has recently become a relevant issue in water quality monitoring and management, and several different approaches have been adopted to distinguish faecal pollution sources. The enumeration of indicator micro-organisms, which is the traditional method in the assessment of health risks for waterborne pathogens, was also the first method applied in tracking sources of faecal pollution.
Nowadays, MST methods can be classified into four main groups: culturing, phenotypic, genetic and chemical. According to the recent literature (Scott et al., 2002; Simpson et al., 2002), the most promising and reliable MST methods available are ribotyping, host-specific genetic markers (genetic methods) and antibiotic resistance analysis (phenotypic method), but more research is needed for each of these techniques before they become the standard MST methods in water quality analysis.

Among the alternatives currently considered, the detection of pharmaceutical and personal care products (PPCPs) seems promising. The key factors in evaluating the reliability of PPCPs are their environmental fate and the correlation to a specific faecal source. Currently, only limited experimental evidence is available to access their applicability as MST methods.

Although the rapid development of genetic techniques and bio-sensors makes us infer that waterborne pathogens will be identified directly, quickly and inexpensively in the near future (Estes et al., 2003), it is likely that the use of traditional faecal indicator organisms will continue to play an important role. It is also unlikely that a unique MST method will be found effective in all possible situations. As recently suggested by Gilpin et al. (2003) and Pickup et al. (2003), the combination of microbial, genetic and chemical methods is probably going to be the optimal solution to distinguish sources of faecal contamination in ground- and surface waters.

\section{References}

ALBERT JM, MUNAKATA-MARR J, TENORIO L and SIEGRIST RL (2003) Statistical evaluation of bacterial source tracking data obtained by rep-PCR DNA fingerprinting of Escherichia coli. Environ. Sci. Technol. 37 4554-4560.

ALKAN U, ELLIOT DJ and EVISON LM (1995) Survival of enteric bacteria in relation to simulated solar radiation and other environmental factors in marine waters. Water Res. 29 2071-2081.

ATHERHOLT T, FEERST E, HOVENDON B, KWAK J and ROSEN JD (2003) Evaluation of indicators of fecal contamination in groundwater. J. Amer. Water Wks. Ass. 95 119-131.

BALDY-CHUDZIK K, NIEDBACH J and STOSIK M (2003) RepPCR fingerptinting as a tool for the analysis of genomic diversity in Escherichia coli strains isolated from an aqueous/freshwater environment. Cell. Mol. Biol. Lett. 8 793-798.

BARNES KK, KOLPIN DW, MEYER MT, THURMAN EM, FURLONG ET, ZAUGG SD and BARBER LB (2002) Water-Quality Data for Pharmaceuticals, Hormones, and Other Organic Wastewater Contaminants in U.S. Streams, 1999-2000. (Available from http://toxics.usgs.gov/pubs/OFR-02-94/index.html ) Accessed on 27 August 2005

BERNHARD AE and FIELD KG (2000a) A PCR assay to discriminate human and ruminant feces on the basis of host differences in Bacteroides-Prevotella genes encoding 16S rRNA. Appl. Environ. Microbiol. 66 4571-4574.

BERNHARD AE and FIELD KG (2000b) Identification of nonpoint sources of fecal pollution in coastal waters by using host-specific 16S ribosomal DNA genetic markers from fecal anaerobes. Appl. Environ. Microbiol. 66 1587-1594.

BERNHARD AE, GOYARD T, SIMONICH MT and FIELD KG (2003) Application of a rapid method for identifying fecal pollution sources in a multi-use estuary. Water Res. 37 909-913.

BERNSTEIN BB, GRIFFITH JF and WEISBERG SB (2002) Microbiological Source Tracking Workshop: Summary of Proceedings. (Available from ftp://ftp.sccwrp.org/pub/download/PDFs/Micro source tracking_wkshop/epa_workshop_summary.pdf ) Accessed on 27 A $u$ ugust 2005.

BILA DM and DEZOTTI M (2003) Pharmaceutical drugs in the environment. Quim. Nova 26 523-530.

BINETTI R, ATTIAS L, DI MARZIO G, CALCINAI D and CAVALLI L (2000) Environmental risk assessment of linear alkyl benzene, 
an intermediate for the detergency industry. Int. J. Environ. Health Res. 10 153-172.

BITTON G and GERBA CP (1984) Groundwater Pollution Microbiology. Wiley International.

BLACKWELL T (2003) Antimicrobial Growth Promoters what good are they? (Available from http://www.gov.on.ca/OMAFRA/english/livestock/swine/facts/info_hh_antimicrobial.htm ) Accessed on March 2004

BOOTH AM, HAGEDORN C, GRAVES AK, HAGEDORN SC and MENTZ KH (2003) Sources of fecal pollution in Virginia's Blackwater River. J. Environ. Eng.129 547-552.

BORGES LGD, DALLA VECHIA V and CORCAO G (2003) Characterization and genetic diversity via REP-PCR of Escherichia coli isolates from polluted waters in southern Brazil. FEMS Microbiol. Ecol. 45 173-180.

BORJESSON E, SUNDIN A, LEEMING R and TORSTENSSON L (1999) New method for determination of fecal sterols in urine using non-chlorinated solvents J. Chromatogr. B 713 438-442.

BOXALL ABA, KOLPIN DW and SØRENSEN BH (2003) Are veterinary medicines causing environmental risk? Environ. Sci. Technol. 37 265A-304A.

BOXALL ABA, FOGG LA, BLACKWELL PA, KAY P, PEMBERTON EJ and CROXFORD A (2004) Veterinary medicines in the environment. Rev. Environ. Contam. Toxicol. 180 1-91.

BOYD GR, REEMTSMA H, GRIMM DA and MITRA S (2003) Pharmaceuticals and personal care products (PPCPs) in surface and treated waters of Louisiana, USA and Ontario, Canada. Sci. Total Environ. 311 135-149.

BUERGE I.J, POIGER T, MULLER MD and BUSER HR (2003a) Caffeine, an anthropogenic marker for wastewater contamination of surface waters. Environ. Sci. Technol. 37 691-700.

BUERGE IJ, BUSER HR, MULLER MD and POIGER T (2003b) Behavior of the polycyclic musks HHCB and AHTN in lakes, two potential anthropogenic markers for domestic wastewater in surface waters. Environ. Sci. Technol. 37 5636-5644.

BURKHARDT MR, SOLIVEN PP, WERNER SL and VAUGHT DG (1999) Determination of submicrogram-per-liter concentrations of caffeine in surface water and groundwater samples by solid-phase extraction and liquid chromatography. J. AOAC Intern. 82 161-166.

CALCI KR, BURKHARDT W, WATKINS WD and RIPPEY SR (1998) Occurrence of male-specific bacteriophage in feral and domestic animal wastes, human feces, and human-associated wastewaters. Appl. Environ. Microbiol. 64 5027-5029.

CARLSEN L, METZON MB and KJELSMARK J (2002) Linear alkylbenzene sulfonates (LAS) in the terrestrial environment. Sci. Total Environ. 290 225-230

CARSON CA, SHEAR BL, ELLERSIECK MR and ASFAW A (2001) Identification of fecal Escherichia coli from humans and animals by Ribotyping. Appl. Environ. Microbiol. 67 1503-1507.

CARSON CA, SHEAR BL, ELLERSIECK MR and SCHNELL JD (2003) Comparison of ribotyping and repetitive extragenic palindromic-PCR for identification of fecal Escherichia coli from humans and animals. Appl. Environ. Microbiol. 69 1836-1839.

CLARA M, STRENN B and KREUZINGER N (2004) Carbamazepine as a possible anthropogenic marker in the aquatic environment: investigations on the behaviour of Carbamazepine in wastewater treatment and during groundwater infiltration. Water Res. 38 947954.

CLOSE ME, HODGSON LR and TOD G (1989) Field-Evaluation of fluorescent whitening agents and sodium tripolyphosphate as indicators of septic-tank contamination in domestic wells. NZ J. Mar. Freshw. Res. 23 563-568.

COLE D, LONG SC and SOBSEY MD (2003) Evaluation of F+ RNA and DNA coliphages as source-specific indicators of fecal contamination in surface waters. Appl. Environ. Microbiol. 69 6507-6514.

CONBOY MJ and GOSS MJ (2000) Natural protection of groundwater against bacteria of fecal origin. J. Contam. Hydrol. 43 1-24.

DAUGHTON CG and TERNES TA (1999) Pharmaceuticals and personal care products in the environment: Agents of subtle change? Environ. Health Perspect. 107 907-938.

DAUGHTON, CG and JONES-LEPP T (2001) Pharmaceuticals and Personal Care Products in the Environment - Scientific and Regu- latory Issues. American Chemical Society, Washington, DC.

DICUONZO G, GHERARDI G, LORINO G, ANGELETTI S, BATTISTONI F, BERTUCCINI L, CRETI R, DI ROSA R, VENDITTI $M$ and BALDASSARRI L (2001) Antibiotic resistance and genotypic characterization by PFGE of clinical and environmental isolates of enterococci. FEMS Microbiol. Lett. 201 205-211.

DOMBEK PE, JOHNSON LK, ZIMMERLEY ST and SADOWSKY MJ (2000) Use of repetitive DNA sequences and the PCR to differentiate Escherichia coli isolates from human and animal sources. Appl. Environ. Microbiol. 66 2572-2577.

ECKEL WP, ROSS B and ISENSEE RK (1993) Pentobarbital found in ground water. Ground Water 31 801-804.

EL FANTROUSSI S, URAKAWA H, BERNHARD AE, KELLY JJ, NOBLE PA, SMIDT H, YERSHOV GM and STAHL DA (2003) Direct profiling of environmental microbial populations by thermal dissociation analysis of native rRNAs hybridized to oligonucleotide microarrays. Appl. Environ. Microbiol. 69 2377-2382.

ESTES C, DUNCAN A, WADE B, LLOYD C, ELLIS WJ and POWERS L (2003) Reagentless detection of microorganisms by intrinsic fluorescence. Biosens. Bioelectron. 18 511-519.

FARNLEITNER AH, KREUZINGER N, KAVKA GG, GRILLENBERGER S, RATH J and MACH RL (2000) Comparative analysis of denaturing gradient gel electrophoresis and temporal temperature gradient gel electrophoresis in separating Escherichia coli uidA amplicons differing in single base substitutions. Lett. Appl. Microbiol. 30 427-431.

FERRER I and THURMAN EM (2003) Liquid chromatography/timeof-flight/mass spectrometry (LC/TOF/MS) for the analysis of emerging contaminants. TrAC, Trends Anal. Chem. 22 750-756.

FIELD KG, BERNHARD AE and BRODEUR TJ (2003) Molecular approaches to microbiological monitoring: Fecal source detection. Environ. Monit. Assess. 81 313-326.

FOUT GS, MARTINSON BC, MOYER MWN and DAHLING DR (2003) A multiplex reverse transcription-PCR method for detection of human enteric viruses in groundwater. Appl. Environ. Microbiol. 69 3158-3164.

FROMME H, OTTO T and PILZ K (2000) Polycyclic musk fragrances in different environmental compartments in Berlin (Germany). Water Res. 35 121-128.

GARTEN CT, (2006) Relationships among forest soil C isotopic composition, partitioning, and turnover times. Canadian J. For. Res. 36 2157-2167

GASPARD PG and SCHAWARTZBROD J (1995) Helminth Eggs in wastewater: quantification technique. Water Sci. Technol. 31 443446.

GAUN SK, XU RL, CHEN S, ODUMERU J and GYLES C (2002) Development of a procedure for discriminating among Escherichia coli isolates from animal and human sources. Appl. Environ. Microbiol. 68 2690-2698.

GAVINI F (2003) BIFID-Project. (Available from http://www.inra.fr/ bifid-project/index.htm ) Accessed on 27 August 2005.

GELDREICH EE and KENNER BA (1969) Concepts of fecal streptococci in stream pollution. J. Water Pollut. Contr. Fed. 41 R336R352.

GELDREICH EE (1976) Fecal Coliform and Fecal Streptococcus density relationships in waste discharges and receiving waters. CRC Critical Review in Environmental Control 349-369.

GILPIN B, JAMES T, NOUROZI F, SAUNDERS D, SCHOLES P and SAVILL M (2003) The use of chemical and molecular microbial indicators for faecal source identification. Water Sci. Technol. 47 $39-43$.

GILPIN BJ, GREGOR JE and SAVILL MG (2002) Identification of the source of faecal pollution in contaminated rivers. Water Sci. Technol. 46 9-15.

GORDON C and TOZE S (2003) Influence of groundwater characteristics on the survival of enteric viruses. J. Appl. Microbiol. 95 536544.

GRAVES AK, HAGEDORN C, TEETOR A, MAHAL M, BOOTH AM and RENEAU RB (2002) Antibiotic resistance profiles to determine sources of fecal contamination in a rural Virginia watershed. J. Environ. Qual 31 1300-1308. 
HAGEDORN C, CROZIER JB, MENTZ KA, BOOTH AM, GRAVES AK, NELSON NJ and RENEAU RB (2003) Carbon source utilization profiles as a method to identify sources of faecal pollution in water. J. Appl. Microbiol. 94 792-799.

HAIDER S, NAITHANI V, VISWANATHAN PN and KAKKAR P (2003) Cyanobacterial toxins: a growing environmental concern. Chemosphere 52 1-21.

HALLING-SØRENSEN B, NIELSEN SN, LANZKY PF, INGERSLEV F, LÜTZHOFT H-CH and JØRGENSEN SE (1998) Occurrence, fate and effects of pharmaceutical substances in the environment - A review. Chemosphere 36 357-394.

HARTEL PG, SUMMER JD and SEGARS WI (2003) Deer diet affects ribotype diversity of Escherichia coli for bacterial source tracking. Water Res. 37 3263-3268.

HAYASHI Y, MANAGAKI S and TAKADA H (2002) Fluorescent whitening agents in Tokyo Bay and adjacent rivers: Their application as anthropogenic molecular markers in coastal environments. Environ. Sci. Technol. 36 3556-3563.

HEBERER T (2003) Occurrence, fate, and assessment of polycyclic musk residues in the aquatic environment of urban areas - A review. Acta Hydroch. Hydrob. 30 227-243.

HILTON MJ and THOMAS KV (2003) Determination of selected human pharmaceutical compounds in effluent and surface water samples by high-performance liquid chromatography-electrospray tandem mass spectrometry. J. Chromatogr. A 1015 129-141.

HOLM JV, RUGGE K, BJERG PL and CHRISTENSEN TH (1995) Occurrence and Distribution of Pharmaceutical Organic-Compounds in the groundwater downgradient of a landfill (Grindsted, DK). Environ. Sci. Technol. 29 1415-1420.

HOLTS MS and BERNSTEIN SL (1992) Lineal alkylbenzenes in sewage sludge and sludge amended soil. Water Res. 26 613-624.

HUYSMAN F, VAN RENTHERGHEM B and VERSTRAETE W (1993) Antibiotic Resistant Sulpite-Reducing clostridia in soil and groundwater as indicator of manuring practices. Water, Air, Soil Pollut. 69 243-255

ISOBE KO, TARAO M, CHIEM NH, MINH LY and TAKADA H (2004) Effect of environmental factors on the relationship between concentrations of coprostanol and fecal indicator bacteria in tropical (Mekong delta) and temperate (Tokyo) freshwaters. Appl. Environ. Microbiol. 70 (2) 814-821.

JAGALS P, GRABOW WOK and DEVILLIERS JC (1995) Evaluation of Indicators for assessment of Human and Animal fecal pollution of Surface Run-Off. Water Sci. Technol. 31 235-241.

JAGALS P and GRABOW WOK (1996) An evaluation of sorbitol-fermenting bifidobacteria as specific indicators of human faecal pollution of environmental water. Water SA 22 235-238

JAMES A and EVISON L (1979) Biological Indicators of Water Quality. Wiley, New York, NY.

JAYASINGHE LY, MARRIOTT PJ, CARPENTER PD and NICHOLS PD (1998) Supercritical fluid extraction and gas chromatographic electron capture detection method for sterol analysis of environmental water samples. Anal. Commun. 35 265-268.

JENSEN J (1999) Fate and effects of linear alkylbenzene sulphonates (LAS) in the terrestrial environment. Sci. Total Environ. $22693-$ 111.

JØRGENSEN SE and HALLING-SØRENSEN B (2000) Drugs in the environment. Chemosphere 40 691-699.

KHATIB LA, TSAI YL and OLSON BH (2003) A biomarker for the identification of swine fecal pollution in water, using the STII toxin gene from enterotoxigenic Escherichia coli. Appl. Environ. Microbiol. 63 231-238.

KOLPIN DW, FURLONG ET, MEYER MT, THURMAN EM, ZAUGG SD, BARBER LB and BUXTON HT (2002) Pharmaceuticals, hormones, and other organic wastewater contaminants in US streams, 1999-2000: A national reconnaissance. Environ. Sci. Technol. 36 1202-1211.

KÜMMERER K (2001) Pharmaceuticals in the Environment-Sources, Fate, Effects and Risks. Springer, Berlin.

LEE HB, PEART TE and SARAFIN K (2003a) Occurrence of polycyclic and nitro musk compounds in Canadian sludge and wastewater sample. Water Qual. Res. J. Can. 38 683-702.
LEE HB, SARAFIN K, PEART TE and SVOBODA ML (2003b) Acidic pharmaceuticals in sewage - Methodology, stability test, occurrence, and removal from Ontario samples. Water Qual. Res. J. Can. 38 667-682.

LEEMING R, BALL A, ASHBOLT N and NICHOLS P (1996a) Using faecal sterols from humans and animals to distinguish faecal pollution in receiving waters. Water Res. 30 2893-2900.

LEEMING R and NICHOLS PD (1996b) Concentrations of coprostanol that correspond to existing bacterial indicator guideline limits. Water Res. 30 2997-3006.

LEEMING R, BATE N, HEWLETT R and NICHOLS PD (1998) Discriminating faecal pollution: A case study of stormwater entering Port Phillip Bay, Australia. Water Sci. Technol. 38 15-22.

LEUNG KT, MACKERETH R, TIEN YC and TOPP E (2004) A comparison of AFLP and ERIC-PCR analyses for discriminating Escherichia coli from cattle, pig and human sources. FEMS Microbiol. Ecol. 47 111-119.

LIVINGSTON SJ, KOMINOS SD and YEE RB (1978) New medium for selection and presumptive identification of the Bacteroides fragilis group. J. Clin. Microbiol. 7 488-453.

LOFFLER D and TERNES TA (2003) Determination of acidic pharmaceuticals, antibiotics and ivermectin in river sediment using liquid chromatography-tandem mass spectrometry. J. Chromatogr. A 1021 133-144.

LONG SC, SHAFER E, ARANGO FC and SIRACO D (2003) Evaluation of three source tracking indicator organisms for watershed management. J. Water Suppl. Res. Technol. 52 565-575.

LYNCH PA, GILPIN BJ, SINTON L and SAVILL MG (2002) The detection of Bifidobacterium adolescentis by colony hybridization as an indicator of human faecal pollution. J Appl. Microbiol. 92 526533

MAIER RM, PEPPER IL and GERBA CP (2000) Environmental Microbiology. Academic Press.

MALDONADO C, DACHS J and BAYONA JM (1998) Trialkylamines and coprostanol as tracers of urban pollution in waters from enclosed seas: The Mediterranean and Black Sea. Environ. Sci. Technol. 33 3290-3296.

MALICKI J, MONTUSIEWICZ A and BIEGANOWSKI A (2001) Improvement of counting helminth eggs with internal standard. Water Res. 35 2333-2335.

MARA DD and ORAGUI JI (1983) Sorbitol-fermenting Bifidobacteria as specific indicators of human faecal pollution. J. Appl. Bacteriol. 55 349-357.

MARCHESE S, PERRET D, GENTILI A, CURINI R and PASTORI F (2003) Determination of non-steroidal anti-inflammatory drugs in surface water and wastewater by liquid chromatography-tandem mass spectrometry. Chromatogr. 58 263-269.

MARTINS CC, VENKATESAN MI and MONTONE RC (2002) Sterols and linear alkylbenzenes in marine sediments from Admiralty Bay, King George Island, South Shetland Islands. ANSc 14 244-252.

MATTHESS G and PEKDEGER A (1981) Concepts of survival and transport model of pathogenic bacteria end viruses in groundwater. Sci. Total Environ. 21 149-159.

McLELLAN SL, DANIELS AD and SALMORE AK (2003) Genetic characterization of Escherichia coli populations from host sources of fecal pollution by using DNA fingerprinting. Appl. Environ. Microbiol. 69 2587-2594.

MEAYS CL, BROERSMA K, NORDIN R and MAZUMDER A (2004) Source tracking fecal bacteria in water: a critical review of current methods. J. Environ. Manage. 73 71-79.

METCALFE CD, MIAO XS, KOENIG BG and STRUGER J (2003) Distribution of acidic and neutral drugs in surface waters near sewage treatment plants in the lower Great Lakes, Canada. Environ. Toxicol. Chem. 22 2881-2889.

NEBRA Y and BLANCH AR (1999) A New selective medium for Bifidobacterium spp. Appl. Environ. Microbiol. 65 5173-5176.

NEBRA Y, BONJOCH X and BLANCH AR (2003) Use of Bifidobacterium dentium as an indicator of the origin of fecal water pollution. Appl. Environ. Microbiol. 69 2651-2656.

ORAGUI JI and MARA DD (1983) Investigation of the survival characteristic of Rhodococcus coprophilus and certain faecal indicator 
bacteria. Appl. Environ. Microbiol. 46 356-360.

PARVEEN S, PORTIER KM, ROBINSON K, EDMISTON L and TAMPLIN ML (1999) Discriminant analysis of ribotype profiles of Escherichia coli for differentiating human and nonhuman sources of fecal pollution. Appl. Environ. Microbiol. 65 3142-3147.

PARVEEN S, HODGE NC, STALL RE, FARRAH SR and TAMPLIN ML (2001) Genotypic and phenotypic characterization of human and nonhuman E.coli. Water Res. 35 379-386.

PECK AM and HORNBUCKLE KC (2004) Synthetic musk fragrances in Lake Michigan. Environ. Sci. Technol. 38 367-372.

PEPPER IL, GERBA CP and BRENDECKE JW (1995) Environmental Microbiology - A Laboratory Manual. Academic Press, NY.

PETROVIC M, GONZALEZ S and BARCELO D (2003) Analysis and removal of emerging contaminants in wastewater and drinking water. TrAC, Trends Anal. Chem. 22 685-696.

PETROVIC M, ELJARRAT E, DE ALDA MJL and BARCELO D (2004) Endocrine disrupting compounds and other emerging contaminants in the environment: A survey on new monitoring strategies and occurrence data. Anal. Bioanal. Chem. 378 549-562.

PICKUP RW, RHODES G and HERMON-TAYLOR J (2003) Monitoring bacterial pathogens in the environment: advantages of a multilayered approach. Curr. Opin. Biotechnol. 14 319-325.

PIOCOS EA and DE LA CRUZ AA (2000) Solid phase extraction and high performance liquid chromatography with photodiode array detection of chemical indicators of human fecal contamination in water. J. Liq. Chromatogr. Related Technol. 23 1281-1291.

POIGER T, KARI FG and GIGER W (1999) Fate of fluorescent whitening agents in the River Glatt. Environ. Sci. Technol. 33 533-539.

RICKING M, SCHWARZBAUER J, HELLOU J, SVENSON A and ZITKO V (2003) Polycyclic aromatic musk compounds in sewage treatment plant effluents of Canada and Sweden - first results. Mar. Pollut. Bull. 46 410-417.

SACHER F, GABRIEL S, METZINGER M and WENZ M (2003) Pharmaceuticals in ground and surface waters. Chim. 57 29-31.

SAVILL MG, MURRAY SR, SCHOLES P, MAAS EW, McCORMICK RE, MOORE EB and GILPIN BJ (2001) Application of polymerase chain reaction (PCR) and TaqMan (TM) PCR techniques to the detection and identification of Rhodococcus coprophilus in faecal samples. J. Microbiol. Methods 47 355-368.

SCHONNING C, LEEMING R and STENSTROM TA (2002) Faeca contamination of source-separated human urine based on the content of faecal sterols. Water Res. 36 1965-1972.

SCOTT TM, ROSE JB, JENKINS TM, FARRAH SR and LUKASIK J (2002) Microbial Source Tracking: Current Methodology and Future Directions. Appl. Environ. Microbiol. 68 5796-5803.

SCOTT TM, PARVEEN S, PORTIER KM, ROSE JB, TAMPLIN ML, FARRAH SR, KOO A and LUKASIK J (2003) Geographical variation in ribotype profiles of Escherichia coli isolates from humans, swine, poultry, beef, and dairy cattle in Florida. Appl. Environ. Microbiol. 69 1089-1092.

SCRIBNER EA, BATTAGLIN WA, DIETZE JE and THURMAN EM (2003) Reconnaissance data for glyphosate, other selected herbicides, their degradation products, and antibiotics in 51 streams in nine Midwestern States, 2002. US Geological Survey Open-File Report 03-217, pp. 101.

SEDMAK G, BINA D and MACDONALD J (2003) Assessment of an enterovirus sewage surveillance system by comparison of clinical isolates with sewage isolates from Milwaukee, Wisconsin, collected August 1994 to December 2002. Appl. Environ. Microbiol. 69 71817187.

SEILER RL, ZAUGG SD, THOMAS JM and HOWCROFT DL (1999) Caffeine and pharmaceuticals as indicators of waste water contamination in wells. Ground Water 37 405-410.

SEURINCK S, VERSTRAETE W and SICILIANO SD (2003) Use of 16S-23S rRNA intergenic spacer region PCR and repetitive extragenic palindromic PCR analyses of Escherichia coli isolates to identify nonpoint fecal sources. Appl. Environ. Microbiol. $694942-$ 4950.

SIEVERS RE, BARKLEY RM, EICEMAN GA, SHAPIRO RH and WALTON HF (1977) Environmental trace analysis of organics in waste water by glass capillary column chromatography and ancil- lary techniques. J. Chromatogr. 142 745-754

SIMPSON JM, SANTO DOMINGO JWS and REASONER JD (2002) Microbial Source Tracking: State of the Science. Environ. Sci. Technol. 36 5279-5288.

SIMPSON JM, SANTO DOMINGO JWS and REASONER JD (2004) Assessment of equine fecal contamination: the search for alternative bacterial source-tracking targets. FEMS Microbiol. Ecol. 47 65-75.

SINTON LW and FINLAY RK (1998) Distinguishing human from animal faecal contamination in water: a review. NZ J. Mar. Freshw. Res. 32 323-348.

SLIFKO TR, SMITH HV and ROSE JB (2000) Emerging parasite zoonoses associated with water and food. Int. J. Parasitol. 301379 1393.

STANDLEY LJ, KAPLAN LA and SMITH D (2000) Molecular tracers of organic matter sources to surface water resources. Environ. Sci. Technol. 34 3124-3130.

SUMPTER JR (2003) Endocrine disruption in wildlife: The future? Pure Appl. Chem. 75 2355-2360.

SUPRIHATIN I, FALLOWFIELD H, BENTHAM R and CROMAR N (2003) Determination of faecal pollutants in Torrens and Patawalonga catchment waters in South Australia using faecal sterols. Water Sci. Technol. 47 283-289.

TARTERA C and JOFRE J (1987) Bacteriophages active against Bacteroides fragilis in sewage polluted waters. Appl. Environ. Microbiol. 53 1632-1637.

TERNES TA (1998) Occurrence of drugs in German sewage treatment plants and rivers. Water Res. 32 3245-3260.

TOZE S (1999) PCR and the detection of microbial pathogens in water and wastewater. Water Resour. Res. 33 3545-3556.

TRUONG TT, MARRIOTT PJ, PORTER NA and LEEMING R (2003) Application of comprehensive two-dimensional gas chromatography to the quantification of overlapping faecal sterols. J. Chromatogr. A 1019 197-210.

TSAI YL, LE JY and OLSON BH (2003) Magnetic bead hybridization to detect enterotoxigenic Escherichia coli strains associated with cattle in environmental water sources. Can. J. Microbiol. 49 391398.

US-EPA (2001) Protocol for developing pathogen TMDLs. EPA-841-R00-002. U.S. Environmental Protection Agency, Office of Waters. Washington, DC.

US-EPA (2004) Pharmaceuticals and Personal Care Products (PPCPs) as Environmental Pollutants. National Exposure Environmental Laboratory, (Available from http://www.epa.gov/nerlesd1/chemistry/pharma/index.htm ) Accessed on 27 August 2005.

USGS (2001) Target Compounds for National Reconnaissance of Emerging Contaminants in US Streams. (Available from http://toxics.usgs. gov/regional/contaminants.html) Accessed on 27 August 2005.

USGS (2003) Veterinary Medicines in the Environment. (Available from http://toxics.usgs.gov/highlights/vet meds.html ) Accessed on 27 August 2005

USGS (2004) Water Quality Information - Microbial Source Tracking and Detection Techniques. (Available from http://water.usgs.gov/ owq/microbial.html ) Accessed on 27 August 2005.

VENTURA M, ELLI M, RANIERO R and ZINK R (2001) Molecular microbial analysis of Bifidobacterium isolates from different environments by the species-specific amplified ribosomal DNA restriction analysis (ARDRA). FEMS Microbiol. Ecol. 36 113-121.

WEIGEL S, KUHLMANN J and HUHNERFUSS H (2002) Drugs and personal care products as ubiquitous pollutants: occurrence and distribution of clofibric acid, caffeine and DEET in the North Sea. Sci. Total Environ. 295 131-141.

WHEELER AL, HARTEL PG, GODFREY DG, HILL JL and SEGARS WI (2003) Potential of Enterococcus faecalis as a human fecal indicator for microbial source tracking. J. Environ. Qual 31 1286-1293.

WHITLOCK JE, JONES DT and HARWOOD VJ (2002) Identification of the source of fecal coliforms in an urban watershed using antibiotic resistance analysis. Water Res. 36 4273-4282.

WIGGINS CHECK SPELLING BA, CASH PW, CREAMER WS, DART SE, GARCIA PP, GERECKE TM, HAN J, HENRY BL, HOOVER KB, JOHNSON EL, JONES KC, McCARTHY JG, MCDONOUGH JA, MERCER SA, NOTO MJ, PARK H, PHILLIPS MS, PURNER 
SM, SMITH BM, STEVENS EN and VARNER AK (2003) Use of antibiotic resistance analysis for representativeness testing of multiwatershed libraries. Appl. Environ. Microbiol. 69 3399-3405.

WIGGINS BA (1996) Discriminant analysis of antibiotic resistance patterns in fecal streptococci, a method to differentiate human and animals sources of fecal pollution in natural waters. Appl. Environ. Microbiol. 62 3997-4002.

YANG L, CHANG WS and LO HUANG MN (2000) Natural disinfection of wastewaters in marine outfall fields. Water Res. 34 743-750. 